\title{
Role of Ashwagandha Taila Matrabasti in the Management of Katigraha
}

\author{
Research Article
}

\author{
Snehal Vasant Bhende ${ }^{*}$, Shweta Parwe ${ }^{2}$ \\ 1. PG Scholar, 2. Professor and HOD, Department of Panchakarma, \\ Mahatma Gandhi Ayurved College Hospital \& Research Centre, Wardha, Maharashtra, India
}

\begin{abstract}
Background: Katigraha (lumbago)is the condition which is characterised by Stiffness and Pain. Due to Vitiation of Vata in the Katipradesh. About $80 \%$ of the industrial population and $60 \%$ of the general population experience low back pain at some point of their life time due to wrong postural habits and psychological factors. Basti chikitsa is mainly useful in disorders related to Vata Doshas. Matrabasti is a type of Sneha Basti which can be given in all seasons without any strict regimen of Diet. It has Brumhana and Vatashamaka in nature. And Madhur Dravya (Ashwagandha Taila) is one such combination to pacify the Vata in Katigraha. Objectives: To evaluate the efficacy of Madhur Dravya (Ashwagandha Taila) Matrabasti in Katigraha for relieving Pain and Stiffness. Settings and design: This was an open-labelled single arm interventional clinical study. Methods: Fifteen diagnosed case of katigraha were registered from the outpatient and inpatient department of Panchakarma and Madhur Dravya (Ashwagandha Taila) Matrabasti administered for 9 days. Statistical Analysis- The data were statistically analysed by using paired $t$ test. Results: Highly significant $(\mathrm{P}<0.0001)$ result was found in all the assessment parameter like Pain, Stiffness Schober's Test and functional rating Index quaternary. Conclusion: Madhur Dravya (Ashwagandha Taila) Matrabasti is one of the best to relieve Pain and Stiffness in Katigraha.
\end{abstract}

Key Words: Katigraha, Madhur Dravya (Ashwagandhsa Taila), Matrabasti.

\section{Introduction}

Katigraha is the commonest encountered disease. Katigraha is one of the Vatavyadhi which is the problem of lumbar region. Even though this disease is not life threatening but it hampers the daily activity. It is described as a separate disease in the classical text Gadanigraha and Acharya Sharangdhar considered it as a nanatmaja Vatavyadhi. Acharya Shodhayla described that it is a condition characterized by pain and restricted movement of Kati. Kati itself is one of the seats of vatadosha and the root cause of disease is aggravated by Vata (1).

About $60-80 \%$ of world population experience low back pain at some time in their lives. The highest prevalence is among people aged 35- 60 years (2).

Low back pain is a clinical condition in which lot of conditions can be interpreted ranging from spondylolysis, space occupying lesions, tuberculosis of spine, inter vertebral disc prolapse, etc. low back pain is not a onetime phenomenon; rather it is characterized by the commonest presenting symptom is low back pain with or without the pain radiating down the back of the leg (sciatica) (3).

In the chikitsa sutra of Vatavyadhi many Acharyas advised Basti and Acharya Charaka has

\section{* Corresponding Author:}

\section{Snehal Vasant Bhende}

PG Scholar Department of Panchakarma, Mahatma Gandhi Ayurved College Hospital \& Research Centre, Wardha, Maharashtra, India Email Id: drsnehalbhende02@,gmail.com mentioned Matrabasti as a brumhana sneha (4) hence in present Study Matrabasti is selected. Shad skanda is mentioned by Acharya Charak in Viman sthan for bastikarma. Ashwagandha is in the Madhur Skanda. (5). Which exert Vatahara and brumhana action. The main treatment principle to pacify vata is used of Vatahara drugs added with Snigdha Dravya (Tila Taila) having Madhur Vipak (6). The Ashwagandha Taila is such combination to pacify Vata in Katigraha.

Thus in the present comparative study is designed to evaluate the effect of Madhur Dravya (Ashwagandha Taila) Matrabasti with the hypothesis that these basti may prove beneficial in managing the disease pathogenesis by Brumhana and Vatahar property (7).

\section{Aim and Objectives}

To evaluate the efficacy of Madhur Dravya (Ashwagandha Taila) Matrabasti in Katigraha for relieving Pain and Stiffness.

\section{Material and Methods}

A total of 15 patients were registered for the study from the outpatient and inpatient department of Panchakarama mahatma Gandhi Ayurved College Hospital and Research Centre Salod (H), Wardha. Who were diagnosed with Katigraha. Informed consent was obtained from the patients before starting the intervention.

\section{Inclusion Criteria}

A diagnosed case of Katigraha age between 25 to 65 years, irrespective of their sex, economic status, 
religion, and occupation and Clinical symptoms from 6 months to 1 year.

\section{Exclusion Criteria}

- Patients having neurological deficit.

- Lumbar and other intervertebral disc disorders with myelopathy, other disc degeneration and radiculopathy (M51.0of ICD-10).

- Pregnant women, Traumatic patients.

- Associated with simple and compound fractures.

- Matrabasti Ayogya- Patients suffering from piles, debility, anaemia.

\section{Diagnostic Criteria}

- Clinical Examination- Shoola and Sthambana in katipradesha

- Low back pain range of motion flexion by schober's test.

- Negative SLRT

- Radiological Examination like X-ray of lumbar spine.

\section{Investigation for screening:}

RBS were carried out before treatment to exclude diabetic patients because Ashwagandha is one of the Madhur Skanda Dravya.

Table no.1: Treatment Plan

\begin{tabular}{|c|c|c|c|}
\hline Procedure & Drug & Dose & Duration \\
\hline $\begin{array}{l}\text { Deepan and } \\
\text { Pachan } \\
\text { (Appetizers } \\
\text { and } \\
\text { carminatives) }\end{array}$ & $\begin{array}{l}\text { Trikatu } \\
\text { Churna }\end{array}$ & $5 \mathrm{gm}$ & $\begin{array}{l}\text { TID before } \\
\text { food with } \\
\text { warm water } \\
\text { for the first } 3 \\
\text { days }\end{array}$ \\
\hline Matra Basti & $\begin{array}{l}\text { Madhur } \\
\text { Dravya } \\
\text { (Ashwagan } \\
\text { dha Taila) }\end{array}$ & $\begin{array}{l}60 \\
\mathrm{ml}\end{array}$ & $\begin{array}{l}\text { After food } \\
\text { anal route for } \\
9 \text { days. }\end{array}$ \\
\hline
\end{tabular}

\section{Study Duration}

The study lasted 9 days followed by 9 day follow-up period.

\section{Method of Administration}

Purva karma (Pre- Procedural preparation)

- The patient was instructed to come with the taking light diet.

- After that patient subjected to local Abhyanga and Mrudu Swedan over abdomen, thighs, and lumbar region.

\section{Pradhan karma (Procedural preparation)}

- After the Purva Karma Patient was advice to lie down on left lateral position on Basti table with left leg straight and right leg flex.

- Taila applied over the anus in small quantity.

- $60 \mathrm{ml}$ of Koshna Taila (Luke worm oil) taken in syringe and rubber catheter smeared with oil after that catheter was administered into the anus up to the $4 \mathrm{~cm}$.

- After that patient asked to take deep breath.
Pashyat karma (Post-procedural preparation)

- After administration of Basti lie on supine position.

- After 10-15 minutes patient was advice to get up from the table and take rest on bed.

- Basti Pratyagamana Kala (Retention Time of enema) noticed (8).

Table no. 2- Assessment Criteria

\begin{tabular}{|c|c|c|c|}
\hline Sr.no & $\begin{array}{l}\text { Assessment } \\
\text { parameters }\end{array}$ & Observation & Grade \\
\hline \multicolumn{4}{|c|}{ a. Subjective criteria } \\
\hline \multirow{4}{*}{1} & \multirow{4}{*}{$\begin{array}{l}\text { Lumbar pain } \\
\text { (by using } \\
\text { VAS Scale } \\
\text { chart) }\end{array}$} & No pain & Grade 1 \\
\hline & & Minor pain & Grade 2 \\
\hline & & Moderate pain & Grade 3 \\
\hline & & Severe pain & Grade 4 \\
\hline \multirow{6}{*}{2} & \multirow{6}{*}{$\begin{array}{l}\text { Lumbar } \\
\text { Stiffness }\end{array}$} & $\begin{array}{l}\text { Normal } \\
\text { movement }\end{array}$ & Grade 0 \\
\hline & & $\begin{array}{l}0 \text { to } 25 \% \\
\text { Restricted }\end{array}$ & Grade 1 \\
\hline & & $25 \%$ to $50 \%$ & Grade 2 \\
\hline & & $50 \%$ to $75 \%$ & \\
\hline & & Restricted & Grade 3 \\
\hline & & $\begin{array}{l}75 \% \text { to } 100 \% \\
\text { Restricted }\end{array}$ & Grade 4 \\
\hline
\end{tabular}

\section{Objective Criteria \\ Schober's Test}

Schober's Test is a physical examination used in physical medicine and rehabilitation and rheumatology to measure the ability of the patient to flex lower back. While patient is in standing position the examiner make a mark at the level of fifth lumber vertebra (L5) Two point are marked $5 \mathrm{~cm}$ below and 10 $\mathrm{cm}$ above of this point (total of $15 \mathrm{~cm}$ distance.) then the patient is asked to touch his/her toes while keeping the knees straight. If the distance of the two points does not increase by at least $5 \mathrm{~cm}$, then this is a sign of restriction in the lumber flexion (9).

\section{Functional Rating Index}

FRI instrument contains 10 items that measures both pain and function of the spinal musculoskeletal system. Of their 10 items 8 refers to activity of daily living that might be adversely affected by a spinal condition and 2 refer to different attributes of pain (10).

\section{Observation}

The Maximum number of patients was females $(60 \%)$ having chronicity between 6 months to 1 year, Hindu $(80 \%)$, as per occupation (40\%) services, $(33.3 \%)$ labour work and (20\%) Household works, Married $(86.7 \%)$, socio economic status poor class and middle class (33.3\%), mixed diet (60\%), Mandagni, Vishamgni and Tikshnagni (26.7\%), Krura koshta (73.3), Sama Mala (73.3).

The maximum patients was Vatapittaj Prakruti (46.7\%), as per age wise distribution age between 5564 years patients was more in number $(53.3 \%)$, maximum Standing and sitting were position during work $(33.30 \%)$,mode of injury of fall $(40 \%)$ [Table 3]. 
The mean value of Schober's test before treatment were $16.60 \pm 1.24$ which were significantly increases to $18.46 \pm 1.18$ after intervention and after follow up period, it again increases to $20.13 \pm 1.35$. The mean value of FRI questionnaire before treatment was $27.93 \pm 5.49$ which were significantly reduces to $7.93 \pm 2.25$ after intervention. [Table 4]

Table 3- Assessment of effect on therapy on Subjective parameters.

\begin{tabular}{|c|c|c|c|c|c|c|c|}
\hline Sr. No & $\begin{array}{l}\text { Assessment } \\
\text { parameters }\end{array}$ & Grade & $\begin{array}{l}\text { Before } \\
\text { treatment }\end{array}$ & $\begin{array}{c}\text { After } \\
\text { treatment }\end{array}$ & Follow up & $\begin{array}{c}\chi 2 \text {-value } \\
\text { (After F.U) }\end{array}$ & P value \\
\hline \multirow[t]{4}{*}{1} & \multirow[t]{4}{*}{ Lumbar pain } & Grade 1 & $0(0 \%)$ & $5(33.3 \%)$ & $7(46.7 \%)$ & 26.57 & $0.0001, \mathrm{~S}$ \\
\hline & & Grade 2 & $0(0 \%)$ & $8(53.3 \%)$ & $7(46.7 \%)$ & & \\
\hline & & Grade 3 & $6(40 \%)$ & $2(13.3 \%)$ & $1(6.7 \%)$ & & \\
\hline & & Grade 4 & $9(60 \%)$ & $0(0 \%)$ & $0(0 \%)$ & & \\
\hline \multirow[t]{5}{*}{2} & \multirow{5}{*}{$\begin{array}{l}\text { Stiffness in } \\
\text { lumbar region }\end{array}$} & Grade 0 & $0(0 \%)$ & $4(26.7 \%)$ & $8(53.3 \%)$ & 21.56 & $0.0002, \mathrm{~S}$ \\
\hline & & Grade 1 & $0(0 \%)$ & $6(40 \%)$ & $4(26.7 \%)$ & & \\
\hline & & Grade 2 & $3(20 \%)$ & $4(26.7 \%)$ & $2(13.3 \%)$ & & \\
\hline & & Grade 3 & $10(66.7 \%)$ & $1(6.7 \%)$ & $1(6.7 \%)$ & & \\
\hline & & Grade 4 & $2(13.3 \%)$ & $0(0 \%)$ & $0(0 \%)$ & & \\
\hline
\end{tabular}

Table 4- Assessment of effect on therapy on Objective parameters.

\begin{tabular}{|c|c|c|c|c|c|c|}
\hline Sr. No & $\begin{array}{c}\text { Assessment } \\
\text { parameters }\end{array}$ & $\begin{array}{c}\text { Before } \\
\text { treatment }\end{array}$ & $\begin{array}{c}\text { After } \\
\text { treatment }\end{array}$ & Follow up & $\begin{array}{c}\text { t value } \\
\text { (After F.U) }\end{array}$ & P value \\
\hline 1 & Schober's test & $16.60 \pm 1.24$ & $18.46 \pm 1.18$ & $20.13 \pm 1.35$ & 11.52 & $<0.0001 \mathrm{~S}$ \\
\hline 2 & $\begin{array}{c}\text { FRI } \\
\text { questionnaire }\end{array}$ & $27.93 \pm 5.49$ & $7.93 \pm 2.25$ & - & 15.15, & $<0.0001 \mathrm{~S}$ \\
\hline
\end{tabular}

\section{Result}

The result obtained were highly significant $(\mathrm{p}<0.0001)$ which shows that Madhur Dravya (Ashwagandha Taila) Matrabasti was statistically effective in reducing the intensity of symptoms of Katigraha. The result obtained were highly significant $(\mathrm{p}<0.0001)$ in objective Parameters which shows that Madhur Dravya (Ashwagandha Taila) Matrabasti was statistically effective in Increase Range of motion and Daily activities of the subject. With percentage relief obtained was $40 \%$ marked improvement, $46.67 \%$ moderate improvement and $13.33 \%$ mild improvement. [Table 5]

Percentage are calculated from number of patient and the percentage of relief

Table no. 5- Assessment of total effect of therapy on the basis of percentage of relief in subjective parameter.

Total effect of therapy

Complete Remission

$100 \%$ relief in sign and symptoms

\section{Range $\quad \%$ of relief}

Marked Improvement

Moderate Improvement

Mild Improvement

Unchanged were considers complete remission

$75-99 \%$ relief in sign and symptoms

$50-74 \%$ relief in sign and symptoms

$25-49 \%$ relief in sign and symptoms

$<25 \%$ No change in sign and symptoms

\begin{tabular}{|c|c|}
\hline Any pain & $0(0 \%)$ \\
\hline & $6(40 \%)$ \\
\hline $7(46.67 \%)$ \\
\hline
\end{tabular}

\section{Disscussion}

\section{Discussion on disease}

In Ayurvedic classics we find Vata Sthana Kati and Vatavyadhi which refers to the Vyadhis caused by the vitiation of Vata Dosha. Katigraha is not mentioned as a separate disease in Bruhatrayee directly. "Katigraha is the condition in which vitiated Vata Dosha gets situated in the Katipradesh and producing Shoola (Pain) and Stambha (Stiffness). In Katigraha, there will be Stiffness throughout the lower back region, pain and restricted movement. As Acharya Sushruta says that without vitiation of Vata, Shoola cannot be produce (11). And Gada Nigraha clearly states that Shoola is produced due to Stambha which is produced by Nirama and Sama Vayu Movement into Kati (Lumbar region).

\section{Discussion on Drug}

Ashwagandha is one of the Madhura skanda dravya. And in Bhaishajya Ratnavali also mentioned Ashwagandha taila in Vatavyadhi Adhyaya. Ashwagandha taila is a single herbal combination which contains Ashwagandha. Base of potent oil is Tila taila which is Ushna Tiksha Madhur Rasa, Madhur Vipaka, Brumhana, Vikasi, Twak prasadhak (12).

It nourishes and strengthens all the dhatus due to its snigdha,guru guna and ushna virya. It decreases rukshata of Vata Dosha, due to its vikasi guna it reduces spasm and joint pain (13). Ashwagandha is having katu and tikta rasa whereas katu rasa is mentioned as vatakapha shamak and tikta rasa is mentioned as pittakapha shamak Ashwagandha being Vataghna by its 
Ushna Virya. It is Shothahara and Vednasthapan too. Ashwagandha Sidha Taila mentioned for Abhyanga and Matrabsati in Vatavyadhi and General Debility (14).

\section{Discussion on procedure}

Figure 1: Showing the mode of action of matrabasti Mode of Action of Matrabasti

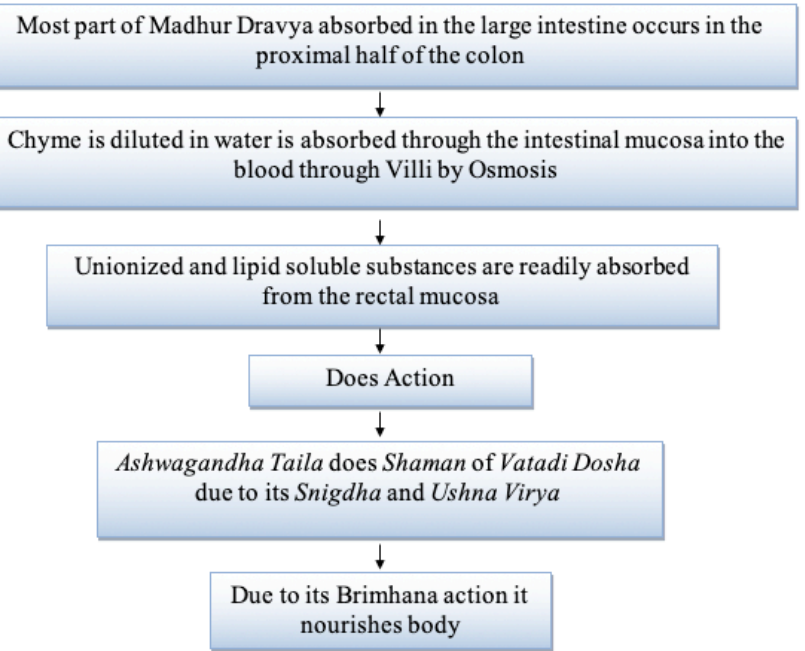

\section{Conclusion}

Katigraha is a common disorder of present era it is Vatapradhan Tridoshaja Vyadhi in Ayurveda based on the similarities in etiological factors, clinical features. Statistically significant reduction in clinical symptoms of Katigraha and significant improvement was found in objective criteria. From the outcomes, we can conclude that Matrabasti with Madhur Dravya (Ashwagandha taila) effective in reducing symptoms of Katigraha.

\section{References}

1. Tripathi Indradeva, Gadanigraha of Vaidya Sodhala with The Vidyotini Hindi commentary,

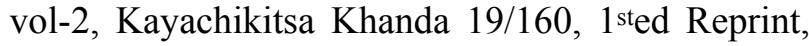
Chaukhambha Sanskrit SansthanVaranashi, 2011, P. 508.

2. Nicholas A. Boon, Nicki R. Colledge \& Brain R. Walker Davidson's Principle \& Practice of medicine. Chapter 25, 20 thed Reprint, Churchil Livingstone ELSEVIER, 2006 P. 1083

3. Jo Jordon, Kika Konstantinou, John O'Dowd, Herniated lumbar disc. Clinical Evidence [PMCID: PMC2907819] 2009 Mar [Clin Evid (Online) 2009; 2009: 1118.] Available from: 2009 March 26 URL: http://www.ncbi.nlm.nih.gov

4. Tripati Brahmanand ed, Charaka Samhita of Agnivesh (Hindi), Vol 2, Siddhisthana 4/52-54,Chaukamba Sanskrit samsthan, Delhi 2005, p. 1223

5. Tripati Brahmanand ed, Charaka Samhita of Agnivesh (Hindi), Vol 2, vimansthana 8/133-143, ChaukambaSanskrit samsthan, Delhi 2005, p. 1223

6. Tripati Brahmanand ed, Ashtang Hridaya ashrimatvagbhat sutra sthan 13/1 Chaukamba Sanskrit samsthan, 2005, p.185

7. Tripati Brahmanand ed, Charaka Samhita of Agnivesh (Hindi), Vol 2, Siddhisthana 4/52-54,Chaukamba Sanskrit samsthan, Delhi 2005, p. 1223

8. Patil V. Principles \& Practice of Panchakarma, Atreya Ayurveda Publications, 3rd Edition, Ilkal;2010; page no.440.

9. https://en.m.wikipedia.org/wiki/Schober\%27s-test [last assessed on date 14 October 2019]

10. Feise R, Menke J, Functional Rating Index. A new valid and reliable instrument to measure the magnitude of clinical change in spinal conditions. Spine volume 26 2001, Lippincott 78-87.[Pub med] [Google Scholar]

11. Shastri Kaviraj. Ambikadatta Edited, Susruta Samhita Shareera 5/30 Choukhamba Sanskrut sansthana Reprint Edition 2005. Page no 46.

12. Chunekar K, Bhavprakash nighantu of Bhavmishra, Purvakhganda in Mishraprakaran, Dhanya Varga 63-65. 2006.

13. Karunagoda K, Shukla (Upadhyaya) K, Donga S, Tanna C, Dei LP. A comparative study of Dashmoola taila Matrabsti and Tila taila matrabasti in Kashtaartava (dysmenorrhea). Ayu. 2010: 31 (3): 305-10.

14. Deshpande A. P, Subhash Ranade ed, Text book of Dravyaguna Vigyan (English), part -2, A. R. Nandurkar, Proficient Publishing House535, Shanivar peth Pune, 2007, p.509. 